\title{
APPARENT JOINDER OF CRIMINAL OFFENSES IN THE CRIMINAL LAW OF SERBIA
}

\begin{abstract}
Apparent joinder of criminal offenses is a legal institute which deviates from the actual or real joinder. It deals with legal situations where one or more criminal acts constitute the substance of several criminal offenses but, for legal and technical reasons, only one criminal offense is considered to have been committed. Following the division of a joinder into ideal and real, where one or several acts of criminal offenses have been taken as a criterion, the apparent joinder is also divided into ideal and real. This practically means that the offender had committed one criminal offense with one criminal act (an apparent ideal joinder) or several acts (an apparent real joinder), regardless whether his/her act or acts constitute the substance of several criminal offenses. Considering the fact that a legal institution of apparent joinder includes an entire catalogue of various legal situations, our legislator stipulates several forms of the apparent ideal as well as the apparent real joinder. They contain modalities of actions constituting the substance of several various criminal offenses. In a criminal theory, the issue of the apparent ideal joinder has occupied the attention of a large number of authors. They have shown an interest in expanding the catalogue of legally defined forms of the apparent joinder of criminal offenses. As a consequence, we have a significantly higher number of forms of the apparent joinder in comparison with the
\end{abstract}

\footnotetext{
*Full professor at the Faculty of Law for Commerce and Judiciary in Novi Sad, Serbia, e-mail: ijoksic@hotmail.rs

(c) () (C) 2021 by the authors. This article is an open access article distributed under the terms and conditions of the Creative Commons Attribution (CC BY) license (https://creativecommons. org/licenses/by/4.0/).
} 
legal framework being used to regulate this institution in our criminal legislature. Therefore, apart from a legal designation, it is necessary to indicate a theoretical designation of both the apparent ideal and apparent real joinders of criminal offenses.

Keywords: apparent joinder, specialty, subsidiarity, consumption, criminal offense.

\section{Introduction}

The original legal memorials do not recognize joinder of criminal offenses as an independent criminal and legal institution. The application of special rules used to regulate the possibility that the offender, with one or several criminal acts, commits the substance of several criminal offenses was completely foreign to the understanding of criminal law in the past. Therefore, it is redundant to discuss the existence of apparent joinder of criminal offenses in such a manner. However, in court proceedings, we can see a hint of awareness that the offender, in certain situations, had acted within the framework of joinder of criminal offenses. At most, the perpetrator was punished more severely if they had committed the substance of several criminal offenses with one or more acts.

The legal institution of joinder of criminal offenses had gradually evolved in such a way that its presence can be seen in the newest codifications. Here, it is reasonable to presuppose the application of an institution that covers situations where the perpetrator, with one or more acts, had committed the substance of several criminal offenses, which are to be arbitrated at the same time. However, apparent joinder of criminal offenses included the introduction of special legal constructions and special rules. This provides the solution for situations where the legislator considers that one and not several criminal offenses exist regardless of the fact that the perpetrator had, with one or more actions, entered the incriminating zone of several criminal offenses.

At present, there is an institution of real and apparent joinder of criminal offenses in national legislatures of a large number of countries. Certain differences can be noted in terms of individual forms of apparent ideal and apparent real joinder of criminal offenses. In international criminal law, the presence of joinder of criminal offenses can be seen in the verdicts of judicial tribunals. We can primarily see that Hague Tribunal had applied joinder of criminal offenses in its verdicts. Based on the practice of Hague Tribunal, it can be concluded that judicial assembly determined in a large number of cases that a certain individual (the defendant) had participated as a perpetrator 
(indirect, direct or co-perpetrator) or as an accessory (in any form or manner of participation in collective criminal offense) in committing a large number of international criminal offenses, meaning, that they had committed multiple violations of the Statute during one event. Consequently, Hague Tribunal applied cumulative indictment, justified by the fact that prior to presentation of evidence (at the main hearing) it was not possible to determine with certainty whether all or only some of the charges would in fact be proven (Jovašević, 2012, p. 94).

\section{The term and meaning of apparent joinder of criminal offenses}

As a rule, the perpetration of criminal offenses by a person through one or several acts is dealt within the framework of real joinder of criminal offenses institution. There are situations when the perpetrator, with one or more perpetrating acts commits several criminal offenses, however, due to their connected nature, only one criminal offense is considered to have been committed. In this case, it only seems that several criminal offenses have been committed, all the while legally they are considered to be one criminal offense. The reason the institution of apparent (unreal) joinder of criminal offenses exists is that in this case, it is criminally and politically unjust to prosecute the defendant for several criminal offenses. Among other things, multiple punishment of a perpetrator is not allowed for the reasons of elementary equity, when in fact only one and not several criminal offenses have been committed.

Ratio legis of apparent joinder of criminal offenses consists of the presence of legal incriminations that contain the substance of several criminal offenses, and therefore it would be unjust to punish the perpetrator two times. This is due to imperfect legal norms, which are a feature of not only our, but also other criminal legislatures. The literature often cites the criminal offense of embezzlement - Article 364 of CC as an example of apparent joinder of criminal offenses, which contains all the elements of the criminal offense of embezzlement - Article 207 of CC. However, in practice, only one criminal offense of embezzlement is considered to have been committed - Article 364, and not the other - Article 207 (Criminal Code, 2005). Differentiating between real and apparent joinder of criminal offenses is based on the fact that in the case of the first, there are several criminal offenses for which the defendant is being tried, while in the second case, only one criminal offense is considered to have been committed regardless of it containing the substance of another criminal offense. Apparent joinder of criminal offenses is manifested 
as apparent ideal and apparent real joinder. Even though there are opposing opinions in criminal theory that negate these forms of joinder, the majority of literature regarding criminal law contains this division (Stojanović, 2006, pp. 220-221).

\section{Apparent ideal joinder}

Apparent ideal joinder exists when the perpetrator commits the substance of two or more criminal offenses with one criminal act, but they are all covered by one criminal offense that contains the substance of other criminal offenses. In order for apparent ideal joinder to exist, there must be a mutual connection of several various substances of criminal offenses. Considering that legal provisions do not determine the elements which would differentiate these types of joinder, it is necessary to rely on the situation in criminal theory and the opinions expressed in court practice (Lazin, 1982, pp. 8-16). ${ }^{1}$ In accordance with this, we can extract several forms of apparent ideal joinder expressed through relations: specialty, subsidiarity, consumption, and other.

\subsection{A case of specialty}

A case of specialty represents a special form of apparent ideal joinder, where the perpetrator commits two criminal offenses with one criminal act, one of which is a special form of other general criminal offense. In this case, only the special criminal offense is considered to exist, as it excludes the existence of the general criminal offense. It is perfectly in accordance with legal maxim expressed in the Latin phrase lex specialis derogat legi generali (special law excludes the general). The application of the specialty case means that one criminal offense contains the substances of two criminal offenses, and so the special criminal offense must contain all legal features of the general criminal offense and an additional feature that makes it special. In practice we see a large number of possibilities for the application of specialty case in relations of two criminal offenses.

Literature points to the possibility of construing a special form of specialty case called concrete specialty. It would be an independent form of apparent ideal joinder, the existence of which requires two conditions to be met

${ }^{1}$ Lazin lists several arguments which are used to justify the existence of apparent ideal joinder of criminal offenses. He points out: 1) legal basis, 2) long application in practice, 3) legislative and political reasons, 4) humanitarian reasons. 
cumulatively: a) that in terms of the perpetrating act there is a relation of specialties between two criminal offenses and b) that all other features of these two criminal offenses (that usually do not overlap) overlap in a specific case. These two forms of specialty differ in that, with concrete specialty, the performing act can be specialized, while other features of two criminal offenses overlap only in a specific case. The specialty and concrete specialty do not differ in any other way (Lazin, 1982, p. 79).

\subsection{A case of subsidiarity}

A case of subsidiarity is listed among the forms of apparent ideal joinder that involve stages of a criminal offense. It exists when a criminal offense is a previous stage of another criminal offense. Here, one criminal offense is subsidiary in relation to the other criminal offense, which is primary. This form of apparent ideal joinder is expressed in the Latin legal phrase lex primaria derogat legi subsidiariae (primary legislation excludes the subsidiary legislation). Therefore, this deals with the relation of two criminal offenses connected by an assault on the same legally protected good, but separated by different stages of their execution. Thereby, the subsidiary criminal offense is limited to preceding or preparatory stages in relation to the primary (main) criminal offense. Criminal theory recognizes various forms of subsidiarity. One of the more significant classifications is into: formal and material subsidiarity.

Formal (explicit) subsidiarity exists when a law excludes the existence of a criminal offense if it contains features of another criminal offense. So, for example, legal description of the criminal offense abuse of the right to strike - Article 167 of CC states that it shall exist unless elements of some other criminal offence entail (Lazin, 1982, p. 88). ${ }^{2}$

Material (silent) subsidiarity stems from the interrelationships of specific criminal offenses. This type of subsidiarity is not precisely set, so it is up to the court practice to estimate its existence in specific cases. As an example of material subsidiarity, literature lists the criminal offense of brawling (Article 123 of (C), which charges those participants of a brawl who cannot be deemed responsible for criminal offenses of murder or serious bodily harm. If that is not the case, then the participants will be held responsible for these criminal offenses for which the criminal offense of participating in a brawl is subsidiary.

\footnotetext{
2 There are opinions based on which subsidiarity cannot exist here at all as both criminal acts occurred at the same time. As opposed to that, there have to be stages of criminal offense in subsidiarity.
} 


\subsection{A case of consumption}

A case of consumption exists when one criminal offense completely consumes the content of another criminal offense. From the perspective of legislature and politics, it is unjust to punish a perpetrator for both acts, as the first criminal offense has all the features of the second (consumed) criminal offense. The relation between two criminal offenses set in such a way, the main (serious) criminal offense is the consumer of the minor criminal offense. Such is the case with the criminal offense of murder - Article 113 of $\mathrm{CC}$, which consumes the criminal offense of serious bodily harm - Article 121 of CC towards the same person (victim). This form of apparent ideal joinder is expressed in the Latin legal phrase lex consumens derogate legi consumptae (one legislation excludes another legislation encompassed by it). Consumption can exist with various forms of complicity, where, for example, one form of complicity (incitement) consumes another form (aiding and abetting). This practically means that a person who participates in the commission of the criminal offense of theft as an inciter and abettor will not be held responsible for abetting, since inciting, as a more serious form of complicity, consumes abetting, a minor form of complicity. Similar case is also with coperpetration, which consumes abetting and inciting as minor forms of complicity. Consumption is possible with both ideal and real joinder of criminal offenses.

\subsection{A case of alternativity}

A case of alternativity exists when one action constitutes the substance of two criminal offenses that a perpetrator can be charged with. In this case, it is alternatively considered that only one criminal offense has taken place (Lazin, 1982, p. 96). ${ }^{3}$ Such is the case with, for example, two forms of the criminal offense aggravated/compound larceny - Article 204 of CC, where one is committed by a group (paragraph 2) and another in a particularly dangerous or brazen manner (paragraph 3 ). This practically means that the perpetrators can be criminally charged for both forms of compound larceny as the content of the criminal offense covers both situations relevant to their existence.

\footnotetext{
${ }^{3}$ Lazin points out the inadequacy of using the phrase alternativity and alternative feature. According to this author, alternation means the choice between two possibilities, and with criminal offenses containing mixed substance, one feature can be determined in more than two ways, so that a choice between more than two options would exist.
} 
However, even though it seems that there are two forms, it is actually only one form of compound larceny for which the perpetrators will be criminally prosecuted. As a result, practice qualifies the existence of only one criminal offense, and the fact that it also constitutes the substance of another criminal offense can be an aggravating circumstance during sentencing.

\subsection{A case of inclusion}

A case of inclusion exists when the perpetrator, while committing one criminal offense (main offense) had committed the legal substance of another criminal offense (secondary offense) that is considered insignificant in comparison with the first, and therefore, it is unjust to punish the perpetrator for both criminal offenses. In this situation, the secondary criminal offense is typically incidental or of accompanying character, and so, from the perspective of presenting danger to society, it is considered completely insignificant in comparison to the main criminal offense. For example, it is insignificant whether a perpetrator had damaged a person's belongings while shooting a victim. The specialty of this form of apparent ideal joinder is seen in the absence of all necessary conditions for the existence of real joinder. This deals with an inclusion of secondary criminal offense into another criminal offense which, in a specific case, is considered to be the main criminal offense. In criminal theory, inclusion is considered to be a special form of consumption, as the main criminal offense consumes the secondary or trivial offense.

\section{Apparent real joinder}

Apparent real joinder of criminal offenses exists when the perpetrator commits several offending acts which constitute the substance of several criminal offenses, and which are considered to be one criminal offense due to their interrelationship. Apparent real joinder manifests as: complex criminal offense, continuing criminal offense and collective criminal offense.

\subsection{Complex criminal offense}

Complex criminal offense exists when two or more criminal offenses, for which the penal law proscribes a unified punishment, are merged into one. Therefore, complex criminal offense did not come to be in a natural way, meaning that it deviates from the natural order of things. It represents a legal construction that artificially merges two or more heterogeneous criminal 
offenses. Literature lists robbery or compound larceny as examples of complex criminal offenses. In both cases, there is a merger of two criminal offenses (larceny and compulsion). They differ only in the temporal moment and the reasons for using compulsion while committing larceny.

The existence of complex criminal offense is based on the will of the legislator, lacking which we would not have a joinder of two criminal offenses (in the previous example of larceny and compulsion). Ratio legis of this legal construction is based on the decision of the legislator to artificially create a completely new criminal offense, for which the perpetrator will be given a single sentence. Lacking this, the rules regarding joinder of criminal offenses would be applied and the perpetrator would be sentenced accordingly. Predominant opinion is that complex criminal offense is more efficient in terms of sentencing a perpetrator as opposed to sentencing for joinder of these criminal offenses.

\subsection{Collective criminal offense}

Collective criminal offense is a legal construction for the existence of which several special conditions need to be met. It consists of several repeated identical criminal offenses that are mutually tightly connected by the decision-making of the perpetrator and the temporal continuity of their perpetration. As with complex criminal offense, here we have an artificial legislative creation, created by the will of the legislator, and which is not possible in nature. This practically means that each individual criminal offense that enters into the composition of the collective criminal offense is completely autonomous and, as such, can exist independently. Collective criminal offense is manifested in forms of trade, occupation and out of habit.

Collective criminal offense in the form of trade exists when the perpetrator repeatedly commits criminal offenses in order to secure a source of income. In this way, the perpetrator acquires goods necessary for basic vital needs. To sum up, by committing criminal offenses in the form of trade, the perpetrator secures the existence for themselves or their family, or, they had the intention of securing a source of income for themselves and their family.

Collective criminal offense in the form of occupation exists when the perpetrator had expressed the decision to repeat the same criminal offense without intent of it being a source of income. Compared with the previous form of collective criminal offense, here, the perpetrator does not need to have the intent of acquiring financial gains, however, the offense will exist even in the case that there actually is intent. 
Collective criminal offense in the form of habit presupposes the existence of tendency of the perpetrator to commit such or similar criminal offenses. With this form of complex criminal offense, it is necessary to determine the tendency to commit criminal offenses for the perpetrator, as such characterization is not possible without this element.

Our criminal legislature does not proscribe collective criminal offenses in the form of trade and out of habit (The Law on Public Peace and Order, 2016). ${ }^{4}$ However, there are collective criminal offenses in the form of trade that are committed through a certain activity. Such is the case with the criminal offense of quackery - Article 254 of $\mathrm{CC}$, which consists of providing medical treatment or issuing medicine by a person who does not have the appropriate expert qualifications.

As a form of apparent real joinder, collective criminal offense had its source in earlier German court practice and criminal theory. However, in Germany, this legal construction was completely abandoned, which brings into question its existence in our criminal law, especially since legislative and political reasons point to the inexpediency of its existence.

Certain dilemmas in criminal theory are provoked by the question whether a collective criminal offense can exist if only one criminal offense has been committed, or whether several criminal offenses are necessary to have been committed. Earlier authors argue for the stance that it is possible even with the perpetration of one criminal offense conditioned that the perpetrator had shown the readiness for this type of criminal offense to serve as their source of income offense in the form of trade (Srzentić \& Stajić, 1954, p. 214). More recent literature abandoned this interpretation and requires the commission of several criminal offenses as a necessary feature for this legislative construction (Babić \& Marković, 2013, pp. 206-207; Stojanović, 2006, p. 225-226; Mrvić Petrović, 2009, p. 225). Debating the argument of the authors that take diametrically opposing stances, we accept the interpretation that several criminal offenses are necessary to have been committed in order for the legislative construction of collective criminal offense to be applied (Babić \& Marković, 2013, p. 207). ${ }^{5}$

\footnotetext{
${ }^{4}$ Criminal offense of gambling - Article 232 of $\mathrm{CC}$ existed in previous legislature, which was done in form of trade. By amending the Criminal Code of Serbia in 2002, this criminal offense was decriminalized and is treated as a misdemeanor - Article 8 .

${ }^{5}$ In that sense, Babić and Marković deem the opposite standpoint unacceptable, since accepting only one criminal offense as sufficient condition for the existence of continuous criminal offense would indirectly establish punishment based on intent, which is not acceptable in modern criminal law.
} 


\subsection{Continuing criminal offense}

Continuing criminal offense (delictum continuatum) is one of the more complex legal constructions, and therefore, significantly more attention is paid to this offense in criminal theory compared with previous forms of apparent real joinder. It exists as a reaction for the application of cumulative system of punishment for a perpetrator who had committed several criminal offenses in a specific temporal continuity. As a result, this form of apparent real joinder was used as an attempt to eliminate unjustly strict punishment for a perpetrator of several criminal offenses. In practice, the application of this form of apparent real joinder was most commonly used for serial killers, thieves, and persons who, during a shorter or longer time period, had repeatedly committed criminal offenses. Even though continuing criminal offense originated in court practice, it is up to criminal theory to define its legal physiognomy, including the conditions necessary for its application, form of punishment, etc. (Bačić, 1998, p. 356). ${ }^{6}$

The term continuing criminal offense can be defined as repetition of several actions that perpetrate the substances of several criminal offenses, but due to their mutual connection, only one criminal offense is considered to exist. The conditions that must be met in order for continuing criminal offense to exist can be divided into: objective and subjective. Objective conditions refer to the criminal actions that enter the composition of the extended criminal offense and are subjective to the psychological mindset of the perpetrator. In criminal theory, there are diverging opinions in regards to prioritizing the objective or the subjective component of the continuing criminal offense institution.

The starting point of objective theory is the objective features of criminal offenses, the criminal contents of which enter into composition of continuing criminal offense. According to this theory, in order for the continuing criminal offense institution to exist, three conditions must be met cumulatively: commonality or a commonality of criminal offenses, temporal continuity of criminal offenses, commonality of the injured party. This practically means that, in each specific case, it is necessary to determine whether all individual conditions have been met in order for the institution of continuing criminal offense

\footnotetext{
${ }^{6}$ Bačić is of the opinion that the institution of continuous criminal offense is unnecessary in modern criminal law, and it is more expedient to consider continuous criminal offense a real joinder of criminal offenses. According to this standpoint, punishment for continuous criminal offense would be measured based on the regulations regarding joinder of criminal offenses, with certain modifications.
} 
to be applied to specific criminal content. In our criminal law, objective theory is accepted in dealing with continuing criminal offense (Živanović, 1935, p. $358-360)^{7}$

a) Commonality or similitude of criminal offenses means that the criminal offenses that enter into the composition of continuing criminal offense must be the same or belong to the same type of offense. Such is, for example, the case when several criminal offenses of theft have been committed during a specific temporal period. It is believed this condition is met when several criminal offenses have been committed, some of which belong to serious and less serious forms of the basic criminal offense (theft and aggravated larceny). However, this condition will not be met if the criminal offenses only belong to the same group of offenses as they do not necessarily belong to criminal offenses of the same type. Such is the case with the criminal offenses of theft and fraud, which belong to the same group of criminal offenses - offenses against property - Chapter XXI of the $\mathrm{CC}$, but they are not considered to be offenses of the same type. Commonality or similitude of criminal offenses requires knowledge of all forms of specific criminal offenses in order for proper evaluation to be made regarding whether the offense is a continuing criminal offense.

b) Temporal continuity of criminal offenses presupposes the existence of a temporal link between several criminal offenses that have been committed. It is evaluated based on the time period between individually committed criminal offenses. The predominant stance of criminal theory is that that the period should be as short as possible, since if the opposite is true, continuing criminal offense is not applicable. However, we find many different situations in practice where the court had confirmed the existence of this condition. It is not rare that the court accepts this legal construction even with longer temporal intervals between criminal offenses if their nature requires special conditions to be perpetrated, such as time of the day or night, weekend, holidays etc.

\footnotetext{
${ }^{7}$ Arguing for objective theory in criminal law, Živanović proposes certain terms or elements to be met for the existence of continuing criminal offense: a) a group of more criminal offenses with several executed acts; b) uniqueness of individual criminal acts, so that they appear as specific cases of the same criminal offense; c) specific criminal offenses are committed by the same person; d) same injured parties for all criminal offenses; d) continuity in committing individual criminal offenses.
} 
c) Commonality of the victim exists when the perpetration of several criminal offenses injures or jeopardizes goods or interests of another person. In one part of criminal theory, this condition is contested as it is believed that in order for continuing criminal offense to exist, various injured parties must exit. In that case, it is necessary for all the criminal offenses encompassed by the continuing criminal offense to be one unified continuous activity that makes a natural whole (Stojanović, 2006, p. 228). ${ }^{8}$

Apart from the objective conditions, subjective-objective theory requires for a subjective condition to be met. It consists of the physiological connection of the perpetrator and the objective elements of the continuing criminal offense, which results in a cohesive unity of all elements. In this way, the entire construction of continuing criminal offense is a unified whole. This practically means that there must be $a$ unified intent which encompasses all criminal offenses and the final consequence of the continuing criminal offense. The existence of unified intent in such extreme form is not acceptable. This would require of the perpetrator to be present from the very beginning, i.e. from the first criminal offense. As a result, criminal theory deems acceptable the institution of extended or continuing intent. It would exist when the perpetrator has shown, so called, initial intent, which would initiate the psychological line. By committing each of the following criminal offenses that enter into the composition of the continuous criminal offense, such intent would only continue the original decision of the perpetrator. This interpretation of continuous criminal offense is not a part of the $\mathrm{CC}$, which is why it is only a theoretical solution.

Considering that continuing criminal offense is a legislative construction, it is necessary to indicate the stance of our legislator, which follows the line of objective theory. Therefore, it excludes the mandatory presence of the

\footnotetext{
${ }^{8}$ This stance is presented in accordance with the conclusions from Counseling at the Supreme Court of Yugoslavia in 1965, where the following conditions were required for the existence of continuous criminal offense: 1) that the same person committed two or more actions of the same type with a temporal distance, each of which individually contains all legal features of the same criminal offense, meaning, their privileged and qualified form; 2 ) that certain time continuity exists between individual criminal activities; 3 ) that all incriminating actions present such a continuous action which makes a natural whole from the standpoint of ordinary and logical observation; 4) that the application of continuing criminal offense in a specific case is not in opposition with the demands of criminal policy, which are expressed in positive criminal-legal regulations. However, the third condition requires for one or more so called variable or alternative elements to be present (using same opportunity, same space, same victim, common intent, and other).
} 
subjective element in continuing criminal offenses. ${ }^{9}$ So, a continuing offence comprises several identical offences of the same type committed in temporal continuity by the same offender, representing a whole, due to existence of at least two of the following requirements: same victim, same type of object of the offense, use of the same situation or same permanent relationship, same places or spaces of commission of the offense or same intent of offenderArticle 61, para. 1 of CC. Following the legal definition of continuing criminal offense, we can distinguish several elements without which the existence of this legal construction is simply not possible. The basic conditions or elements of continuing criminal offense include: several same criminal offenses or offenses of the same type, their temporal connection, same perpetrator, and criminal offenses must make a whole. Apart from that, two special circumstances are required: same victim, same type of object of the offense, use of the same situation or same permanent relationship, same places or spaces of commission of the offense or same intent of offender.

Legal solution of continuing criminal offense presupposes exemptions from general application of this institution. They refer to offenses against person that may constitute continuing criminal offense only when perpetrated against the same person - Article 61, para. 2 of CC. It explicitly prohibits the application of this construction for those offenses that, by their nature, do not allow combining into one offense - Article 61, para. 3 of CC. It is up to the court practice to evaluate in each specific case the nature of the committed criminal offenses the merger of which is not permissible (Lazarević, 2011, p. 293). ${ }^{10}$

When dealing with a situation where a continuing criminal offense comprises several serious and less serious forms of the same offense, it shall be considered that continuing criminal offense constitutes the most serious form of the offenses committed - Article 61, para. 4 of CC. Such is the case, for example, when the perpetrator had committed several criminal offenses of theft, some of which are serous and less serious forms of theft, aggravated larceny shall be considered to have been committed as the continuing criminal offense - Article 204 of CC.

\footnotetext{
${ }^{9}$ As a reminder, CC of RS primarily introduced the construction of continuing criminal offense. In this way, specific framework have been determined that should be used to evaluate the conditions and circumstances for the application of this legal construction. Through its legalization, a significant step has been made in the direction of defining the institution of continuous criminal offense, which was not the case prior to the proclamation of the current CC of RS.

${ }^{10}$ Lazarević believes the application of this provision to be redundant as it enables arbitrariness in the decision of the court. Furthermore, the provisions of Article 61, paragraph 1 of CC of RS clearly states that same offenses or offenses of the same type must be in question, so the introduction of the limitations in paragraph 3 of the same Article is redundant.
} 
The subject of special legislative regulation is the situation when continuing criminal offense includes offenses the special element of which is a pecuniary amount. In this case, it shall be considered that the continuing criminal offense achieved the sum of amounts achieved by individual offenses, if comprised by single intent of the offender - Article 61, para. 5 of CC. Considering the diversity of the offenses committed, there is the question to what degree it is possible to correctly evaluate the criterion of single intent of the offender. If we take into consideration that intent, as a form of guilt, is a subjective element of criminal offense, determining intent requires the evaluation of the psychological relationship between the perpetrator and the criminal offenses that are included in this legislative construction. In our opinion, this will create problems in court practice, which will inevitably lead to arbitrary rulings.

In practice, a situation is possible that a criminal offense is not included in continuing criminal offense in the final court ruling. In this case, it will constitute a separate criminal offense or be a part of a separate continuing office depending on the conditions - Article 61, para. 6 of CC.

\section{Conclusion}

Apparent joinder of criminal offenses is independently regulated in the criminal legislature of Serbia. The essence of apparent joinder of criminal offenses consists of legal incriminations that constitute several criminal offenses, and therefore, double sentencing of a perpetrator would be unjust. Placing the perpetrator in an unfavorable position is avoided in this manner. Thereby, differencing between real and apparent joinder of criminal offenses is based on the fact that, in the first case, there are several criminal offenses for which the perpetrator is being tried at the same time, while in the second case, it deals with one criminal offense regardless whether it contains another criminal offense. From legislative-technical perspective, the provisions that regulate the institution of apparent joinder of criminal offenses are not defined. That is, among other things, a feature of other criminal legislatures. Apparent joinder of criminal offenses is manifested as ideal and real. This division is predominant in criminal theory. It is present in the majority of literature in the field of criminal law. Apparent ideal joinder of criminal offenses is based on the interrelationship of several substances of criminal offenses. Legal provisions do not clearly define the framework for individual forms of apparent ideal joinder. However, in criminal theory and court practice, we can differentiate several forms of apparent ideal joinder, manifested as: specialty, subsidiarity, consumption, and other. Apparent real joinder of criminal 
offenses is based on the fact that the perpetrator, through several offending acts, had committed several criminal offenses that are mutually connected. As a result, only one criminal offense is considered to have been committed. Apparent real joinder is manifested as: complex criminal offense, continuing criminal offense and collective criminal offense. There are individual forms of apparent joinder within each category that can be recognized in the examples of specific criminal offenses (e.g. robbery, continuous theft, etc.)

\section{Joksić Ivan}

Redovni profesor na Pravnom fakultetu za privredu i pravosuđe u Novom Sadu, Univerzitet Privredna akademija u Novom Sadu, Srbija

\section{PRIVIDNI STICAJ KRIVIČNIH DELA U KRIVIČNOM PRAVU SRBIJE}

REZIME: Prividni sticaj krivičnih dela predstavlja pravni institut kojim se odstupa od stvarnog ili realnog sticaja. U pitanju su pravne situacije u kojima se jednom ili sa više radnji ostvaruje biće više krivičnih dela ali se iz pravno-tehničkih razloga smatra da postoji samo jedno krivično delo. Sledeći podelu pravog sticaja na idealni i realni, gde se kao kriterijum uzima jedna ili više radnji krivičnih dela, prividni sticaj se, takođe, deli na idealni i realni. To praktično znači da je učinilac sa jednom radnjom (prividni idealni sticaj) ili sa više radnji (prividni realni sticaj) učinio jedno krivično delo, bez obzira što je njegovom radnjom odnosno radnjama ostvareno biće više krivičnih dela. S obzirom da institut prividnog sticaja podrazumeva čitav katalog različitih pravnih situacija, naš zakonodavac je predvideo više oblika prividnog idealnog i prividnog realnog sticaja. U njima su sadržani modaliteti radnji u kojima se ostvaruje biće više raznorodnih krivičnih dela. U krivičnoj teoriji je pitanje prividnog idealnog sticaja zaokupilo pažnju većeg broja autora. Oni su iskazivali interesovanje za proširenje kataloga zakonski određenih oblika prividnog sticaja krivičnih dela. Otuda imamo znatno veći broj oblika prividnog sticaja u odnosu na zakonske okvire u kojima se ovaj institut reguliše u našem krivičnom zakonodavstvu. Zato je neophodno, pored zakonskog, ukazati na teorijsko određenje prividnog idealnog i prividnog realnog sticaja krivičnih dela. 
Ključne reči: prividni sticaj, specijalitet, supsidijaritet, konsumpcija, krivično delo.

\section{References}

1. Bačić, F. (1998). Krivično pravo: opšti deo [Criminal Law: general section]. Zagreb: Informer

2. Babić, M. \& Marković, I. (2013). Krivično pravo: opšti deo [Criminal Law: general section]. Banja Luka: Pravni fakultet Univerziteta u Banjoj Luci

3. Jovašević, D. (2012). Oblici ispoljavanja međunarodnog krivičnog prava [Forms of international crimes]. Zbornik radova Pravnog fakulteta $u$ Nišu, (62), pp. 91-112

4. Krivični zakonik [Criminal Code]. Službeni glasnik RS, br. 85/05, 88/05ispr., 107/05 - ispr., 72/09, 111/09, 121/12, 104/13, 108/14, 94/16 i 35/19

5. Lazin, Đ. (1982). Prividni idealni sticaj krivičnih dela [Apparent joinder of criminal offenses]. Beograd: Privredna štampa

6. Lazarević, L. (2011). Komentar Krivičnog zakonika [Commentary on the Criminal Code]. Beograd: Pravni fakultet Univerziteta Union

7. Mrvić Petrović, N. (2009). Krivično pravo: opšti deo [Criminal Law: general section]. Beograd: Pravni fakultet Univerziteta Union i JP Službeni glasnik

8. Srzentić, N., \& Stajić, A. (1954). Krivično pravo Federativne Narodne Republike Jugoslavije: opšti deo [Criminal Law of Federal People's Republic of Yugoslavia: General section]. Beograd: Arhiv za pravne i društvene nauke

9. Stojanović, Z. (2006). Krivično pravo: opšti deo [Criminal Law: general section]. Beograd: Pravna knjiga

10. Zakon o javnom redu i miru [The Law on Public Peace and Order]. Službeni glasnik $R S$, br. 6/16, 24/18

11. Živanović, T. (1935). Osnovi krivičnog prava: opšti deo I knjiga [Basis of Criminal Law: General section: book I]. Beograd: Štamparija "Gundulić" 